\title{
An Error Analysis of the Use of Conjunctions in the Chinese Language for Indonesian Students
}

\author{
Dian Lestari \\ University of Maritim Raja Ali Haji, \\ Tanjungpinang Kepri, Indonesia \\ dianlestari@umrah.ac.id
}

\author{
Indah Pujiastuti \\ University of Maritim Raja Ali Haji \\ Tanjungpinang Kepri, Indonesia \\ Indah.pujiastuti26@gmail.com
}

\begin{abstract}
When Indonesian students learn the Chinese language, they could possibly make errors in using conjunctions. This paper discusses the types of errors made by Indonesian students in learning the Chinese language. Above is my analysis result in Conjunction Application Errors in the Chinese Language for Indonesian Students. From the quantitative result, we can conclude that there are errors in the understanding of Conjunction Application for Indonesian students. While using single conjunction word in a sentence we found that there are $22 \%$ of errors; the rate of errors in using the word "so" is $\mathbf{7 0 . 6 \%}$, and the rate of error in using fixed causal conjunction "because ... ... so ......" is $14 \%$ which is the lowest; On the contrary in the use of "because ... ... so ... ..." and "because ... ... and ..." the error rate is as high as $76 \%$. All in all, the average error rate of Indonesian students using single causal conjunctions is as high as $41.41 \%$. The average error rate of causal conjunctions with fixed collocation is as high as $\mathbf{5 6 . 3 9 \%}$. Thus, causal conjunctions are difficult for Indonesian students to master, in the course of the usage, inevitably there will be errors.
\end{abstract}

Keywords: Indonesian students; Conjunctions; discrepancy analysis

\section{INTRODUCTION}

With the development of China's economy, people all over the world have set off an upsurge of learning Chinese. They all learn Chinese as an international second language. One of the most difficult things to learn when learning a foreign language is hard to avoid. One of the hardest parts for Indonesian students in grammar, especially about conjunctions. The causal conjunctions are the highest error rates in all conjunctions class. The difficulty for Indonesian students to learn causal conjunctions lies in the fact that there are few causal conjunctions in Indonesian, and that some causal conjunctions in Chinese have the same meaning when translated into Indonesian. Because in Indonesian expression of causal conjunctions of words is too small. This paper investigates the use of causal conjunctions by Indonesian students, summarizes the types of errors, proposes teaching suggestions and hopes to help Indonesian students learn Chinese.

\section{THE RANGE OF CAUSAL CONJUNCTIONS}

Causal conjunctions in modern Chinese include the following: [1] Because: Conjunctions that indicate causation, used in the previous clause of the causal complex, leads to the occurrence or existence of a situation. Such as:

(1) The plane was late because of the bad weather
"Because" often "paired" with "so", formally, it forms the "because ... so ..." format. Can also be with "on" with, constitute "because ............" format. Such as:

(2) Because I am sick, I can not go to class today.

(3) Because you are so beautiful, can you be so proud?

The partial sentence with "because" can also be placed behind the positive sentence, still, explain the reason. Such as:

(4) He did not come to class because he was ill.

[2]. Because: Conjunctions that indicate causation, put the reason in the previous clause (strong written language). Such as:

(5) Due to the rapid development of modern science and culture, the proliferation of books has led to the continuous evolution and innovation of the forms of bibliography.

"Because" is often used in conjunction with "so", "therefore" and "therefore" and constitutes "by ..., so ...", "... by ..., ..." "by ... ..." format. Sometimes with "and" collocation, forming "due to ... and ..." format. Such as:

(6) Since I worked with him, I am more familiar with him.

(7) As the Pharaoh is sick, today's meeting was canceled.

(8) Due to the complexity of the issue and the different views of the people, the opinions are not entirely consistent.

(9) My Chinese has progressed slowly, and I soon gave up learning because I lost my confidence.

[2] So: Conjunctions that indicate causality, associative causal and corollary causative sentences. For the latter clause, indicate the result. Such as:

(10) I worked with him, so I was more familiar with him.

"The reason" and "so" mean the same thing, but for the first clause of a complex sentence, the beginning of the second clause should be used because "the connection" constitutes "the reason why ... because ..." Format is written language. Such as:

(11) The reason why my father looks depressed is because my brother is still absent from school.

4. Therefore: causal conjunctions, that result. Such as:

(12) His words led everyone to laugh, the air in the room, so a lot easier.

5. Thus: causal conjunctions, said the results. Such as:

(13) his family is very favorable conditions, smart-minded, handsome appearance, which won the girls favor

6. To this end: causal conjunction, said the result. Such as:

(14) I bought new shoes, but I lost it on my way back to Beijing, and I was depressed for that.

7. Results: Associative causal complex sentence or sentence group, cannot be associated causal complex sentence or sentence group, said the results. Such as:

(15) Because coal blocks hurt the leg, for several months cannot go to work, the result called the road bureau set down.

8. Therefore: that result (classical Chinese). Such as: 
(16) Due to the lack of political control over the overall situation, the maintenance of internal capabilities and the military's modest military strategy, the founding of the People's Republic of China started as a mere formalist in the world.

9. Because: that reason (classical Chinese). Often with the "and" with, into "because of ......" format. Such as:

(17) Because made Yuqing Palace, cutting mountains draw, square someone see it.

(18) Lan Lan was rewarded by the municipal government for his filial piety to his mother.

10. And even (to): used at the beginning of the second sentence, said the previous clause of the situation and have some kind of result, but the result is not necessarily bad, it can be good or normal situation. In addition, the range, the number,

Degree, time and other extensions and development, generally refers to small to large, as small as possible, from shallow to deep. Such as: (19) At border points such as fruit and vegetable hemp, the good things that are united are endless, and the pergola alone shows a unity that makes it hard to find uncoalesced people and things. (Indicating good or normal result)

(20) It seems like literature has a magic power that pulls us into another world of fantasy, so much so that I have completely forgotten where I am. (Indicates bad or abnormal results)

(21) From the coastal cities and vast rural areas, everywhere is a thriving moving scene. (Indicating range)

(22) To learn to swim, you must practice once, twice or ten times. (Indicating time, quantity)

(23) In our country, we must never allow discrimination and abuse of women. (Degree of representation)

11. So that: used in the latter clause. Emphasizes that B is affected by A, which is often the result of poor or abnormal behavior, which the speaker does not want. "So" sometimes used in conjunction with "as / because" constitutes a "due / ... because ..." format. Such as:

She stared so attentively that I stood at the door for a long time, and she did not notice either.

(25) Because / because his neck is too low, so that others can not see the expression on his face.

12. To: (conjunctions) used in the latter clause, the result is often not good, not normal. (Verb) For some reason. As [3]:

(26) The letter cannot be delivered due to unclear writing. (conjunction)

(27) Dozens of houses collapsed as a result of heavy rains. (verb)

13. inevitably: that for the reasons previously cannot avoid some negative results. Such as:

(28) Life's road will inevitably encounter setbacks.

14. Is inevitable: that the unwanted results of some circumstances. Such as:

(29) language barrier, it is inevitable misunderstanding.

15. So: that the latter thing followed the previous one, the latter incident is often caused by the previous event. Such as:

(30) As soon as you encouraged me, I resumed my faith.

16. Thus: causal relationship. That the end of the development of changes in things, said the previous clause is not based on what is the reason. Often with the "due" with the formation of "as ..., and thus ......" format. Such as:

(31) He often talked to Chinese people, thus raising his proficiency in Chinese.

(32) Due to the rapid development of transportation, it has provided more favorable conditions for the exchange of urban and rural materials.

\section{INVESTIGATION ON THE USE OF CAUSAL CONJUNCTIONS OF INDONESIAN STUDENTS}

In order to understand what problems occur when Indonesian students learn causal conjunctions, the author uses a questionnaire to study the situation. There are two contents of the questionnaire: the first is the indefinite multiplechoice questions, a total of 34 questions, the second is to determine the right and wrong, a total of 41 questions. [4] In 75 questions, each causal conjunction has two, three, four or five topics. The causal conjunctions for both topics are: "Because of ..., ...", "Because of ..., ...", "Because ..., ...", "Because of ..., ..." because " / Because of ..., ... "," So "," So "," Result "," Cause "," Unavoidable "," Unavoidable "," So "," So "and" due ". The causal conjunctions for the three topics are: "Because of ..., ...", "... because ...", "because of ...", "because ..., ..." and " So ". The causal conjunctions for the four topics are: "Because ..., so ...", "because", "for this", "even", "caused", and "made". The causal conjunctions of the five topics are "so". The author's topic is selected from the beginning of HSK, intermediate exercises and grammar book, sent to 25 Indonesian students to fill out the questionnaire. According to the time they learned Chinese, the 25 Indonesian students were divided into three groups: nine Chinese for two years, twelve Chinese for three years and four Chinese for four years. The following is the statistics of the survey results.

TABLE I QUESTIONNAIRE SINGLE WITH CAUSAL CONJUNCTIONS ERROR STATISTICS

\begin{tabular}{|c|c|c|c|c|c|c|c|c|c|}
\hline & $\begin{array}{c}\text { 因 } \\
\text { 为 }\end{array}$ & $\begin{array}{c}\text { 由 } \\
\text { 于 }\end{array}$ & $\begin{array}{c}\text { 以 } \\
\text { 以 }\end{array}$ & 因此 & $\begin{array}{c}\text { 因 } \\
\text { 而 }\end{array}$ & $\begin{array}{c}\text { 为 } \\
\text { 此 }\end{array}$ & $\begin{array}{c}\text { 结 } \\
\text { 果 }\end{array}$ & 故 & 因 \\
\hline $\begin{array}{c}\text { 两年 } \\
(9 \\
\text { 个人 } \\
)\end{array}$ & 16 & 7 & 8 & 14 & 5 & 23 & 3 & 6 & 12 \\
\hline $\begin{array}{c}\text { 三年 } \\
(12 \\
\text { 个人 } \\
)\end{array}$ & 19 & 12 & 9 & 18 & 8 & 26 & 6 & 12 & 7 \\
\hline $\begin{array}{c}\text { 四年 } \\
(4 \\
\text { 个人 } \\
\text { ) }\end{array}$ & 3 & 1 & 2 & 6 & 1 & 1 & 3 & 1 & 0 \\
\hline $\begin{array}{c}\text { 错误 } \\
\text { 率 }\end{array}$ & $38 \%$ & $40 \%$ & $38 \%$ & $30.4 \%$ & $28 \%$ & $50 \%$ & $24 \%$ & $38 \%$ & $38 \%$ \\
\hline
\end{tabular}

\begin{tabular}{|c|c|c|c|c|c|c|c|c|c|}
\hline & $\begin{array}{c}\text { 以 } \\
\text { 至 }\end{array}$ & $\begin{array}{c}\text { 以至 } \\
\text { 于 }\end{array}$ & $\begin{array}{c}\text { 以 } \\
\text { 致 }\end{array}$ & $\begin{array}{c}\text { 致 } \\
\text { 使 }\end{array}$ & $\begin{array}{c}\text { 不 } \\
\text { 免 }\end{array}$ & $\begin{array}{c}\text { 难 } \\
\text { 免 }\end{array}$ & $\begin{array}{c}\text { 于 } \\
\text { 是 }\end{array}$ & $\begin{array}{c}\text { 从 } \\
\text { 而 }\end{array}$ & $\begin{array}{c}\text { 错坮 } \\
\text { 率 }\end{array}$ \\
\hline $\begin{array}{c}\text { 两 } \\
\text { 年 } \\
\left(\begin{array}{c}9 \\
\text { 个 } \\
\text { 人 } \\
\text { ) }\end{array}\right.\end{array}$ & 22 & 21 & 23 & 29 & 6 & 8 & 11 & 11 & \\
\hline $\begin{array}{c}\text { 兵 } \\
\text { ( }\end{array}$ & 19 & 24 & 18 & 33 & 5 & 3 & 10 & 10 & \\
\hline
\end{tabular}




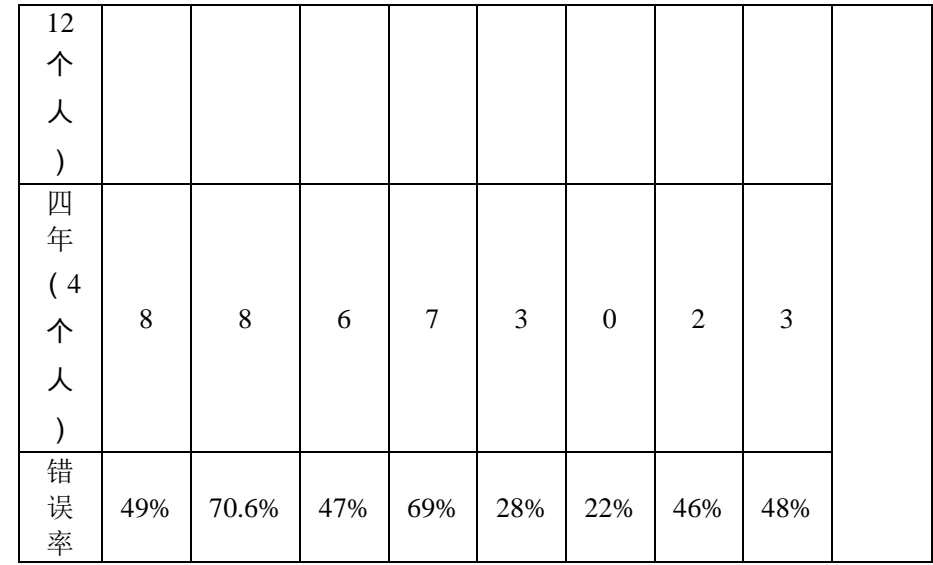

TABLE II. QUESTIONNAIRE FIXED WITH CAUSAL CONJUNCTIONS ERROR STATISTICS

\begin{tabular}{|c|c|c|c|c|c|c|c|c|}
\hline & $\begin{array}{c}\text { 因 } \\
\text { 为 } \\
\ldots \\
\ldots \\
\text {, } \\
\text { 所 } \\
\text { 以 } \\
\ldots \\
\ldots\end{array}$ & $\begin{array}{c}\text { 由 } \\
\text { 于 } \\
\ldots \\
\ldots \\
\text {, } \\
\text { 因 } \\
\text { 此 } \\
\ldots \\
\ldots\end{array}$ & $\begin{array}{c}\text { 由 } \\
\text { 于 } \\
\ldots \\
\ldots \\
\text {, } \\
\text { 因 } \\
\text { 而 } \\
\ldots \\
\ldots\end{array}$ & $\begin{array}{c}\text { 由 } \\
\text { 于 } \\
\ldots \\
\ldots \\
\text {, } \\
\text { 所 } \\
\text { 以 } \\
\ldots \\
\ldots\end{array}$ & $\begin{array}{c}\text { 因 } \\
\text { 为 } \\
\ldots \\
\ldots \\
\text {, } \\
\text { 就 } \\
\ldots \\
\ldots\end{array}$ & $\begin{array}{c}\text { 因 } \\
\ldots \\
\ldots \\
\text {, } \\
\text { 而 } \\
\ldots \\
\ldots\end{array}$ & $\begin{array}{c}\text { 之 } \\
\text { 所 } \\
\text { 以 } \\
\ldots \\
\ldots \\
, \\
\text { 是 } \\
\text { 因 } \\
\text { 为 } \\
\ldots \\
\ldots\end{array}$ & $\begin{array}{c}\text { 由于 } \\
\ldots \ldots \\
\text {, 从 } \\
\text { 而 } \\
\ldots . . .\end{array}$ \\
\hline $\begin{array}{c}\text { 两年 } \\
\text { (9个 } \\
\text { 人 ) }\end{array}$ & 8 & 8 & 18 & 14 & 16 & 22 & 9 & 10 \\
\hline $\begin{array}{c}\text { 三年 } \\
(12 \\
\text { 个人 } \\
\text { ) }\end{array}$ & 5 & 12 & 26 & 20 & 16 & 28 & 12 & 10 \\
\hline $\begin{array}{c}\text { 四年 } \\
\text { ( } 4 \text { 个 } \\
\text { 人 ) }\end{array}$ & 1 & 2 & 11 & 4 & 5 & 7 & 2 & 3 \\
\hline $\begin{array}{c}\text { 错误 } \\
\text { 率 }\end{array}$ & $14 \%$ & $44 \%$ & $\begin{array}{c}73.3 \\
\%\end{array}$ & $76 \%$ & $74 \%$ & $76 \%$ & $\begin{array}{c}30.6 \\
\%\end{array}$ & $46 \%$ \\
\hline
\end{tabular}

\begin{tabular}{|c|c|c|c|}
\hline & $\begin{array}{c}\text { 由于/因 } \\
\text { 为 } \ldots . . . \\
\text { 以致 } \\
\ldots \ldots .\end{array}$ & $\begin{array}{c}\text { 由于..., } \\
\text { 而...... }\end{array}$ & $\begin{array}{c}\text { 平均错 } \\
\text { 误率 }\end{array}$ \\
\cline { 1 - 2 } $\begin{array}{c}\text { 两年 } \\
(9 \text { 个人 })\end{array}$ & 12 & 16 & \\
\hline $\begin{array}{c}\text { 三年 } \\
(12 \text { 个人 })\end{array}$ & 16 & 25 & \multirow{2}{*}{$56.39 \%$} \\
\cline { 1 - 2 } $\begin{array}{c}\text { 四年 } \\
(4 \text { 个人 })\end{array}$ & 5 & 7 & \\
\cline { 1 - 2 } 错误率 & $66 \%$ & $64 \%$ & \\
\hline
\end{tabular}

The above is the author of Indonesian students use causal conjunctions bias survey results. Statistics from the above can be found, Indonesian students have some discrepancies in the causal conjunction. The lowest error rate was $22 \%$ when using the causal conjunctions for single causal conjunctions and $70.6 \%$ for those using causal affixes, and the use of causal conjunctions "because of ..., so ..." The rate is also the lowest, at $14 \%$; on the contrary, the use of "as ..., so ..." and "because of ... and ..." error rate as high as $76 \%$. All in all, Indonesian students use a single causal conjunction average error rate as high as $41.41 \%$, the use of fixed causal conjunction average error rate as high as $56.39 \%$. This shows that causal conjunctions are very hard for Indonesian students to master and will inevitably lead to errors during their use.

\section{TYPES OF ERRORS THAT INDONESIAN STUDENTS USE CAUSAL CONJUNCTIONS}

Causal conjunctions in the use of which there are certain rules, alone or with other words to use, must be based on need. Because of the subtle differences between synonymous causal conjunctions, the use rules of causal conjunctions and the influence of mother tongue, Indonesian students inevitably encounter mistakes in the actual application of causal conjunctions. According to the errors that Indonesian students use when investigating causal conjunctions, I found that the mistakes made by Indonesian students mainly appear in the following aspects: the wrong words and the multiple words.

(A) the wrong word

A. Synonymous causal conjunction of the wrong use Indonesian students

are not sure about the subtle differences between synonym causal conjunctions, making them inaccessible:

(1) Liquor should not replace the cooking wine, which is because the alcohol content of liquor is higher than cooking wine.

Change: liquor instead of cooking wine, it is because the alcohol content of liquor is higher than cooking wine.

(2) But when I grow up, I find this attitude is not good, because it will make you more helpless and incompetent.

Change: But when I grow up, I found this attitude is not good because it will make you more helpless and more incompetent.

(3) My house is small and I cannot stay, so stay somewhere else.

Change: I am a small house, but also cannot stay, so / so you still find another place to live it.

(4) She thought she seemed to need to explain to him about the situation, and personally went to visit.

Change: She felt like it necessary to tell him about the situation, so personally went on a trip.

"Because", "Because" and "Because" similar meaning, but there are still some differences in the usage. "Because" and "Because" are mostly used in written language, "because" is mostly used in spoken language. "Because" and "Because" cannot be placed in the latter clause, but "because" can. So Example (1) should be "because of" changed to "because." Example (2) should be "due to" changed to "because." "So" indicates causality only when expressing causation, while case (3) only has causality and no coherence, so "should" be replaced by "so", "hence" or "thus". If the previous clause expresses feelings or feelings, the latter clauses indicate that the resulting result is "yes", so case (4) should change "from" to "then".

B. Formal misuse of causal conjunctions

Some of the causal conjunctions have very similar infections to other words, which are easily intermingled by Indonesian students during their use. E.g: 
(5) [5] Increased smoking population by adolescents, smoking more and more. Therefore, various countries implement various kinds of prevention strategies.

Change: Due to the increase in smoking population among young people, the amount of smoking is also increasing. Therefore, various countries implement various kinds of prevention strategies.

(6) He read books fascinated, so even forgot to eat rice.

Change: He read the book fascinated, so even forgot to eat rice.

(7) Dozens of houses collapsed when it rained.

Change: This heavy rain caused dozens of houses to collapse.

(8) Because everybody eats the crop that uses the pesticide, the physical quality is getting worse and worse. As for not eating vitamin, the medicine such as calcium cannot live as normal as usual and often get sick.

Change: Because everyone ate pesticides used in crops, physical quality is getting worse, so that do not eat vitamin supplements, calcium and other drugs cannot live in the past as normal, often sick.

Example (5) wrong in the "by" as "due." "Both" and "since" have different parts of speech and meaning, "from" is not conjunctions, and it is a preposition and a verb. Therefore, Example (5) should change "from" to "due to". Example (6) mixed "and" and "so." The result, "even", is not necessarily bad, it can be good or normal. The "result" is often not good, the abnormal is the speaker does not want to appear. Therefore, in (6) the word "to" should be replaced by "even". Example (7) Wrong in the mix "cause" and "cause." If the result is not good, abnormal, is the speaker does not want to appear, in this case, "caused" is equivalent to "so."

However, due to the inclusion of the word "make", "induced" more emphasized the significance of triggering and causing some consequence. But "cause" can be a verb except when it can be a conjunction, and "so" can only be conjunctions. Example (7) The word "cause" should be replaced by "cause", where "cause" is not a conjunction but a verb. Example (8) Wrong in the "as for" as "so." "As for" is a verb, which is completely different from the meaning and the meaning of "To". Therefore, we should change "as for" to "as for".

C. with improper

Some causal collocation is fixed, can not be changed. Indonesian students are often mistaken with the above, often forget it with a fixed mix:

(9) The reason why you are so beautiful, you can be so proud?

Change: Because you are so beautiful, you can be so proud?

(10) Lan Lan because of her very filial piety, it won the municipal government awards.

Change: Lan Lan because of her very filial piety, and won the municipal government incentives.

(11) Because of the complexity of the issue and the different viewpoints of each person, the opinions of the two parties are therefore not entirely consistent.

Change: Due to the complexity of the issue and the different opinions of different people, the opinion of the two parties is therefore not entirely consistent.

(12) Due to the rapid issuance of transportation, more powerful conditions have been provided for the exchange of urban and rural materials.

Change: Due to the rapid issuance of public transport, urban and rural areas to provide a more effective exchange of conditions.

(13) Because they had both hands clasped, they held the enemy so tight that they could not be separated from each other, breaking some of their fingers.

Change: Because of their hands clasped, holding the enemy so tight, cannot be separated from each other, so that some of the fingers were broken.
(14) This holiday, because I am a person in the spacious room at night, I feel a long time, but I helped those who need, I find it very meaningful.

Change: This holiday, although I was a person to stay in the spacious room at night, I feel a long time, but I helped those who need help, that makes sense.

Example (9) In front of "why", followed by "on" to match, obviously no such match. The fixed format "because of ..., is ..." should be used. Example (10) Wrong in the "cause" as "because." "Because" cannot be used with "so", only "because" can be used together with "so". It should be "so" replaced by "and", into "... and ......" fixed format. Example (11) Wrong in "because" cannot be used with "therefore / thus", "because" can only be used with "so" together. "Because" can match with "so", "therefore" and "thus", Example (11) should change "because" to "due".

Example (12) There is a causal coherence relationship between the ancestry before and after the clause. The application of "due to" and "thus" does not have the matching format of "due to ......, ......". Example (13) Wrong There is no "because ..., and thus ... ..." This format. "The fact that they clasped their hands and hold the enemy so tight they could not be separated" was the result of "breaking some of their fingers" and applying the "... as ..." format. Example (14) In front of "because", followed by "but", with improper, the causal relationship and transition relations mix. Observation shows that the transition between the sentence before and after the relationship, therefore, should be replaced by "because" although.

D. White no distinction

In modern Chinese, causal conjunctions have different degrees of whiteness. Indonesian students often only know the meaning of a word when using causal conjunctions, and do not know what kind of genres the term applies to. Therefore, mistakes often occur when using causal conjunctions. As [6]:

(15) because of making Yu-Qing Palace, cutting mountains draw, square someone see it.

Change: Due to make Yuqing Gong, cutting mountains draw, square someone see it.

(16) For example, since adolescents are very young and their life experiences have not informed them that smoking is harmful to them, it undoubtedly makes them vulnerable to smoking.

To change: For example, since adolescents are very young, their life experiences have not informed them that smoking is harmful to them. Therefore, it undoubtedly makes them vulnerable to smoking.

(B) more words

Indonesian students often add unwanted ingredients when writing essays. Causation conjunctions will make the sentence appear very wordy and awkward. Such as:

(17) The reason I went home after my holiday was because I loved my hometown so much.

Change: I went home to a holiday because I love my home too.

Example (17) Wrong in the "reason" and "because" repeat, keep one on it.

\section{TEACHING SUGgESTIONS}

According to the above error analysis of causal conjunctions of Indonesian students, the author makes the following suggestions on the teaching of causal conjunctions: First of all, teachers should pay enough attention to the teaching of causal conjunctions. In the process of learning causal conjunctions, it is best to review the simple, commonly used causal conjunctions, and to introduce causal conjunctions that are seldom used in practice after learning simple, commonly used causal conjunctions. Teachers should add targeted exercises or assignments for causal conjunctions. 
From the above, we can see that Indonesian students' understanding of causal conjunctions is problematic. Judging from the causal conjunctions themselves, some of them have low usage rates, but they must be used in order to express our meaning more accurately. Therefore, I think the teaching of causal conjunctions should pay attention.

Second, from the mistakes students have, I believe that teachers should pay attention to these two aspects when they teach causal conjunctions: First, the subtle differences of synonymous causal conjunctions. Synonymous causal conjunction learning and mastery of foreign students is the difficulty. For example, "due", "because", and "due", when students encounter these causal conjunctions when learning causal conjunctions, teachers should carefully explain and analyze their subtle differences with students to enable students to correctly use. Second, the causal conjunction of a fixed match. Students often fail to learn causal conjunctions with collocation, and they do not quite understand the fixed collocation of causal conjunctions.

For example, "because ..., so ...", "... because of ..., ..." because $" . . .$, therefore ..." and "because ..., so ...", students often confuse this Fixed with or forgotten its fixed mix. Therefore, teachers should pay more attention to this aspect when teaching causal conjunctions. The teacher should do more exercises and assignments to the students in the classroom. The teacher should repeat as much as possible the learned knowledge so that the students are very impressed.

However, for Indonesian students, in order to understand causative conjunctions more accurately and accurately, students should consciously use causal conjunctions when they talk to teachers, students in other countries and Chinese students to enhance practical ability. Except for speaking, students must also consciously use causal conjunctions when writing essays, so that students are greatly assisted in understanding causal conjunctions.

In addition, teachers must use appropriate teaching methods when teaching causal conjunctions. The author believes that teachers should adopt a comparative teaching method. Teachers should pay attention to guiding students to compare "together", "from" to "from" to "even", "from" to "from" "from", "from" The Similarities and Differences of the Synonymous Causative Conjunctions of "Hence",
"So" and "So". The author also suggests that teachers correct and strengthen the practice of error-prone knowledge points based on their mistakes. Above I have analyzed the Indonesian students for learning causal association error-prone type, should pay more attention in teaching, consciously strengthen these aspects of teaching, thereby reducing the error rate of students.

Causal conjunctions are really difficult for Indonesian students and can not be done overnight. However, the points mentioned above can help Indonesian students to break through the bottleneck and master the key points of learning causal conjunctions more effectively in a shorter period of time.

\section{CONCLUSION}

For a long time, mistakes made by Indonesian students in some universities in our country using causal conjunctions accounted for a considerable proportion. Therefore, how to carry out effective teaching and research on the mistakes and difficulties that Indonesian students have in learning Chinese. This paper investigates the use of causal conjunctions. The author finds that the main types of errors that Indonesian students use when they use causal conjunctions include "Mistake Words" and "Multi-Words", and puts forward corresponding teaching suggestions according to the errors of Indonesian students, Hoping to the causal association of learning and teaching helpful.

\section{参考文献:}

[1] 刘月华, 实用现代汉语语法, 1st ed. 中国: 商务印书版, 2010.

[2] 邢福义, 复句关系标记的搭配研究. 中国: 华中师范大学出版社, 2008.

[3] 吕叔湘, 现代汉语词典. 中国: 商务印书馆, 2014.

[4] 朱庆明, 现代汉语实用语法分析. 中国: 清华大学出版社, 2005 .

[5] 彭小川、李守纪、王红, 对外汉语教学语法释疑. 中国: 商务印书馆, 2005

[6] 倪重阳, “现代汉语因果连词研究,”2008 